\title{
The South Dakota Pine Bark Beetle Caper
}

\author{
Adrian Stephen Juttner ${ }^{1}$, Daniel Paul Checkman ${ }^{2}$ and Darrell Dean Magnus ${ }^{3}$ \\ 1. Adrian's Tree Service Inc., Abita Springs, Louisiana 70420, USA \\ 2. Res. \& Dev. Healthhelp LLC., Houston, Texas 8122, USA \\ 3. Magnus \& Johnson Tree Service, 1131 Colorado Ave., Laurel, Montana 59044, USA
}

\begin{abstract}
The aim of this study is the creation of a new, economical and bio-rational control protocol for epidemic infestations of mountain pine beetles (Dendroctonous ponderosae). A comparison of eight different materials for mortality to mountain pine beetle (Dendroctonous ponderosae) done in 2002 was interrupted by a seven year hiatus. Field preparations of an entomopathogenic fungus (Zygomycetes: Entomophthorales) sprayed into colonies of Formosan subterranean termites (Coptotermes formosanus) in trees in the New Orleans area since 1997, Boxelder bugs in Montana, homopterous sucking insects on citrus and early instar buck moth (Hemileuca maia) caterpillars in oaks trees, gave us excellent routine operational control for a number of years. From 2009 to 2013 , numerous field sites in South Dakota, Montana and Colorado were sprayed with a mixture of entomopathogenic fungus (Zygomycetes: Entomophthorales) mixed with the nematode Steinernema carpocapsae in a preparation, which we call "Pork'n'beans". And the experiment produced dramatic positive results. These results, recorded in this paper, were repeatedly suppressed by the state and federal government-sponsored forestry establishment. Description of the work and a discussion of possible motives are included.
\end{abstract}

Key words: Entomophthorales, Zygomycetes, Dendroctonous ponderosae, Steinernema carpocapsae, Formosan subterranean termite (Coptotermes formosanus).

\section{Introduction}

The town of Deadwood, South Dakota was so named because it was founded in the middle of a forest of beetle-killed Ponderosa pine trees around 1870. The first government scientist came to the Black Hills to study pine bark beetles in 1906. Today, this insect (Dendroctonous ponderosae) and its relatives are at the center of an unfolding catastrophe of dead trees, forest fires, floods and landslides all over the American West. This is not one of the science's most shining moments. Apologists will say that the underlying cause is the global warming and the exclusion of fire with the concomitant buildup of fuels in the west. This paper will suggest otherwise. We will suggest that the cause is a perfect storm of bad science, a gridlock of environmental laws and fascist-style bureaucratic bungling. Perhaps, the proof will be found in the photos,

Corresponding author: Adrian Stephen Juttner, M.Sc., research field: biocontrol of a root disease in a tree nursery. E-mail: adriantree@aol.com. tables and anecdotes here. Then, certainly a pattern of persecution, stonewalling, bullying and threats that we have received from the western forestry establishment, would cause any reasonable person to wonder. Had it not been for the late cooperation of Mr. Art Janklow of the Mystery Mountain Resort of Rapid City, South Dakota - acts of insubordination, criminal trespass, civil disobedience and the passage of more than a decade, this paper would not have been possible.

Here in the Southern United States, there has several species of bark beetles infesting pine. Bark beetles in industrial pine forests are controlled mostly by eradication. The forest is scouted for areas of infestation and the timber is harvested immediately. Turpentine beetles breed in cut stumps, so annual clear-cut areas are separated by large buffers of uncut forest to prevent buildups. Sprinkler systems are laid atop log piles at mills to prevent buildup of bark beetles. New bark beetle infestations are known to be initiated by simply being on the truck route to the mill! 


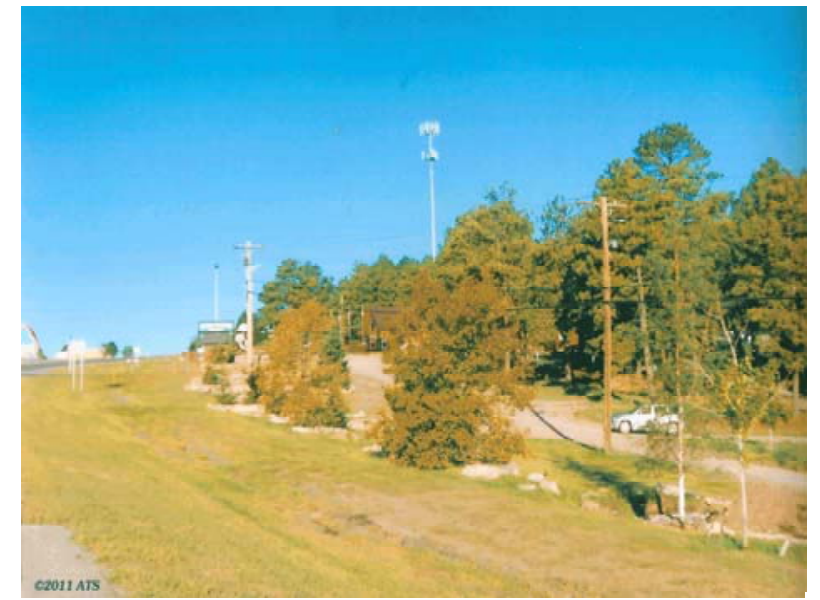

Fig. 1 Mystery Mountain Resort on US 16, West of Rapid City, SD.

Beetles leave pine logs and hit new pine trees on the way. Southern forests are blessed with diversity. There are four major species of southern pines and at least five minor ones. The land mass of the south is more diverse, with pine forests interspersed with cypress and tupelo swamps, extensive hardwood stands and agricultural areas. There is no diversity in the Black Hills of South Dakota, with the Black Hills variety of Ponderosa pine-the sole pine species, which makes up some $80 \%$ of the forest cover. Most of the forested area consists of government-owned lands and amenity forests. Industrial forest land areas are insignificant. Early detection and eradication of infested trees is not an option and the use of sprinkler systems to control beetle buildups in stored logs is unknown.

Later, Dr. Anderson [1], the author's advisor at the Duke University Forestry School, wrote and lectured about pheromone-mediated mass attacks of conifers by bark beetles [2]. A typical mass-attacked (green hit) pine tree would have about 300 beetle hits. Each hit would contain about 30 developing larvae. This yields a potential of about 9000 adult beetles emerging from a single tree-enough to infest and kill more than 10 acres of pine trees. A logical control strategy would target the larval stage of the insect under the bark of mass-attacked pine trees. This would be done by scouting and then spraying the trunks of "green hits" with an effective insecticide. This has been the standard procedure in western forests for decades. The problem is that the only effective pesticide is Lindane or Gamma benzene hexachloride. It is a potential carcinogen and persists too long in the environment. It has been banned by the Environmental Protection Agency (EPA). Traditional sprays were a nasty mix of Lindane and diesel oil. These were applied to trunks of infested trees with backpack pump sprayers. Operators would clean out clogged nozzles by placing them in their mouth and blowing. Since there is no effective substitute on the market and the pesticide shelf in South Dakota is nearly bare, a subtle bait-and-switch has been made. Sevin and Permethrin insecticides are incapable of killing beetle grubs under the bark of pine trees. But, they are now recommended as a prophylaxis to spray on all the uninfected pine trees in a stand. This would turn an insecticide into an insect repellent. That means that a private forest owner in the Black Hills would be required to annually spray a big chunk of expensive and ineffective chemicals, which are nerve poisons and can be absorbed through the skin or inhaled, simply to keep beetles away. The potential for collateral damage to the environment is enormous. This is the opposite to the spot treatment of only infested trees and leaving the rest of the environment alone. The repellency idea is being stretched with Verbenone-based treatments, which are poisonous and also very expensive.

Entomophthoralean fungi are highly specialized killers of insects. Massospora spp. is elegant predators of cicadas [3]. They lie in the soil as resting spores for as much as 17 years before infecting emerging cicada nymphs. The mature cicada flies off and spreads infection to new areas [4]. Other species attack the brains of grasshoppers and take control of the insect host. The infected grasshopper is directed to climb to the highest stalk of grass and thus increase the trajectory of ejected spores. Attempts at using this mixed with agricultural oil as a bio-control in Africa 
were to minimize desiccation. The introduced Gypsy moth (Lymantria dispar) has been controlled by moving the resting spores of Entomophaga maimaiga in a soil mix to new areas of heavy infestation, causing a new population collapse [5]. To date, this fungus cannot be grown on agar media. Harvesting resting spores of Neozygites fresenii is done by mass-rearing on the cotton-aphid host to move infection to new cotton fields [6]. The beauty of using "Our fungus" is that it can be grown en masse on agar plates using special media and inoculation techniques without the necessity of collecting resting spores in the field or mass rearing on susceptible insects. Post-log cultures can simply be blenderized and placed into a tank mix. Stability and activeness seem to be increased by adding a bit of molasses, an agricultural oil adjuvant or a silicone-based surfactant to tank mixes, at an optimal temperature range (5-30 $\left.{ }^{\circ} \mathrm{C}\right)$ and higher humidity. The nematode pathogen-Steinernema carpocapsae, shown to be effective in the field [7], was added for, hopefully, greater activeness.

\section{Materials and Methods}

\section{1 "Our Fungus” and Koch's Postulates}

Before gathering the materials for the Derby, we performed Koch's postulates to see if, indeed, "Our fungus" was capable of killing the larval stage of Dendroctonous ponderosae. There was some doubt, after all, since previous test on Tribolium castaneum and small hive beetles in Louisiana failed to produce significant mortality. Fructifications of "Our fungus" are apparent in lactophenol-cotton blue stained larvae, viewing at $100 \times$. And the infection from these was successfully passed to new beetle larvae and recovered in culture. Koch's postulates were fulfilled.

\subsection{South Dakota Bark Beetle Derby}

During February to April 2002, the areas of Black Hills National Forest were scouted to locate green, beetle-infested trees. On April 15, 2002, six infested
Ponderosa pine trees, ranging from 12 inches to 24 inches diamter at breast height (DBH) were felled, bucked into 2-foot sections and hauled to the equipment yard of the South Dakota Department of Resource Conservation \& Forestry in Rapid City. The logs were oriented vertically and the top of each was painted with white latex paint to reduce the effects of desiccation over the duration of the experiment. The logs were grouped into nine groups, which represent the materials to be tested and plus an untreated control.

Lindane was obtained from pre-ban inventory in Louisiana and was mixed with water (not diesel oil) at the label rate of $0.156 \%$; Carbaryl (Sevin $50 \% \mathrm{WP}$ ) was mixed with water at the label rate of $0.926 \%$; Permethrin (sold as "Astra" in South Dakota) was mixed with water at the label rate of $0.316 \%$; Disodium octaborate (Tim-bor), labeled for control of

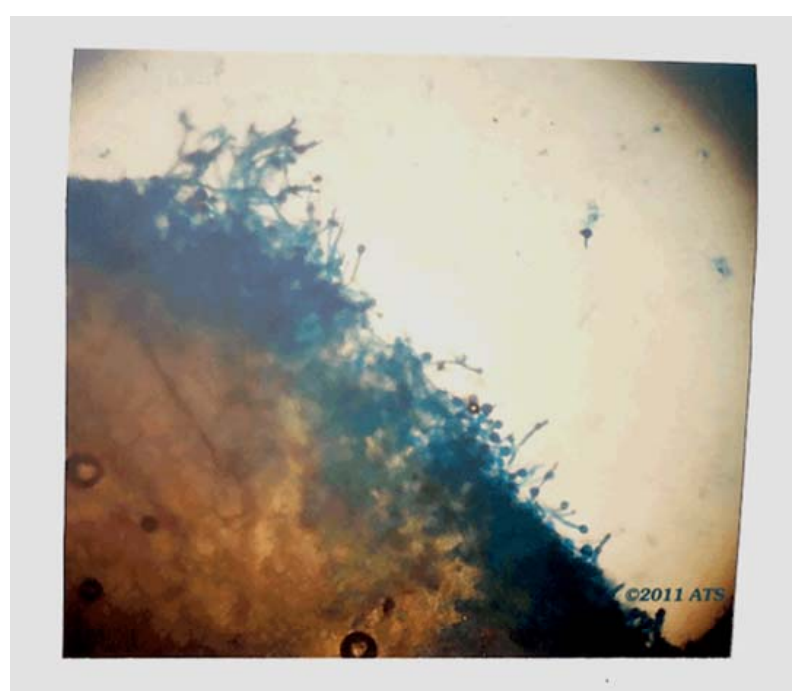

Fig. 2 Fructifications of "Our fungus" on the cuticle of Dendroctonous ponderosae grubs at $100 \times$.

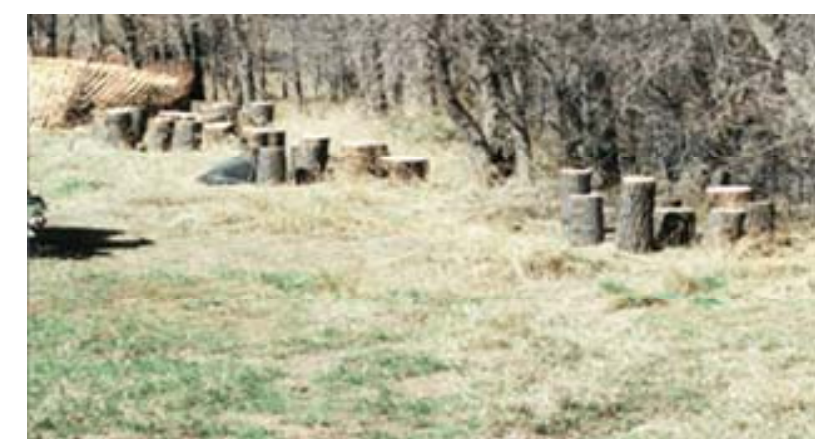

Fig. 3 Infested pine bolts grouped for treatments at the SD forestry equipment yard, Rapid City, March 2002. 
bark beetles but not available in South Dakota, was brought up from Louisiana and mixed with warm water to dissolve all solids at the low dose (10\%) label rate. The biologicals were mixed at comparable rates, since none of these were labeled for bark beetle control. Bacillus thuringiensis var. San Diego, which is labeled for the control of Elm leaf beetle, was mixed at the label rate for that insect. Metarhizium anisopliae, sold as a termiticide in Texas under the "bio-blast" label, is a common fungus used in entomology and was applied at the label rate. "Our fungus" spore suspension was obtained by blenderizing the product of 4 post-log (approxmately 5-day old cultures on petri dishes) into $1 \mathrm{~L}$ water and then using $50 \mathrm{~mL}$ of this mixture together with an additional $1 \mathrm{~L}$ water as a final spray solution. Steinernema carpocapsae is sold as "Termask" by Rincon-Vitova Insectaries, Ventura, California. It comes into packets containing 50 million worms. Approximately 5 million worms were mixed with $1 \mathrm{~L}$ water to make up the final spray solution for its group of $\log$.

Mixtures of each, appropriately measured insecticide, were loaded into a "Windex-type" hand pump sprayer and all the log in a group were sprayed until run off. The control group was sprayed first with plain water. No stickers, wetting agents, brighteners or anti-desiccants were used. Individual $\log$ were selected from each group periodically. Bark squares around entry holes were chiseled away, revealing the cambium and the developing beetle grubs. At least 100 individuals were examined from each group at each time frame. A 4-week interval from the initial spray was selected because of a good dispersion. The results are listed in Table 1.

\subsection{Treatment of Infested Pine Trees in the Field 2009, 2011 and 2013}

Before planning a mass treatment, the forest needs to be scouted and all the infested pine trees marked with log marking paint at breast height mean facing out of the woods, so they can be easily located and
Table 1 Mortality of bark beetle grubs in four weeks after treatment.

\begin{tabular}{ll}
\hline Treatment & $\%$ \\
\hline Control & 7 \\
Lindane (benzene hexachloride) in water & 77 \\
Carbaryl (Sevin) & 15 \\
Permethrin (Astra) & 7 \\
Disodium octaborate 10\% (Tim-bor) & 54 \\
Metarhizium anisopliae (sold as "Bioblast") & 29 \\
Bacillus thuringiensis var. San Diego (for beetles) & 19 \\
"Our fungus" & 65 \\
Steinernema carpocapsae nematodes & 92 \\
\hline
\end{tabular}

accessed. Trees at Mystery Mountain were differentially marked with Nelson aerosol with symbols particular to the treatment year, so that trees could be differentiated by year of treatment and detailed assumptions. To avoid detection on National Forest property, the trees were sprayed first and then grossly marked with Nelson red boundary marking paint from gallon cans with a brush just before leaving the scene. A 5-gallon tub of disodium octaborate was left at Mystery Mountain Resort for spot treatments of new beetle hits by the operators there in off-years when we were not present. It was deemed safe and its effectiveness could be boosted by the addition of $0.3 \%$ of an excellent surfactant $(100 \%$ polyether-polymethlysiloxane-copolymer; from Southern States, Inc. Richmond, VA). We applied only a mixture of "Our fungus" + Steinernema carpocapseae that we call "Pork'n'beans". Because we had confidence in the mixture from a long application history in Louisiana and because it was a bonafide, non-chemical biological control agent. Field application required the use of a Stihl (R) SR-450 mistblower powered by a small gasoline engine. With the aperture set at the maximum output, this machine could be easily transported into the woods and be able to reach 30 feet up the trunks of at least 10 infested pine trees on a single $16 \mathrm{~L}$ spray tank. Field mixtures of "Pork'n'beans" were mixed at the concentrations listed before, except that $2 \%$ Safety oil ("Tri-tek" brand of $80 \%$ emulsified mineral oil from Brandt Consolidated Int., www.brandt.co) and $2 \%$ molasses 
(purchased in bulk, by the ton in 30 gallon plastic barrels from the sugar refinery in New Iberia, Louisiana), were added to the mixture to serve as a brightener and anti-desiccant. The 2009 and 2011 trips to the Black Hills were made in rented Chevy HHR cruisers out of Louisiana that were packed with gear. By 2013, Mystery Mountain had its own mist blower and an inventory of materials, so the trip could be made by commercial airline at a significantly lower cost with $4 \mathrm{~d}$ less time spent on the road.

\section{Results}

\subsection{South Dakota Bark Beetle Derby}

After four weeks, a good dispersion between the eight treatments and the controls had occurred. The dispersion became apparent in as short as $2 \mathrm{~d}$ after treatment. When beetle grubs were examined at the 4th week, the dead ones had already began to disintegrate in the galleries, making a tally more difficult and possibly leading to an under-count of the higher mortality groups. Deaths of beetle grubs were more likely to occur after $21 \mathrm{~d}$ than after $2 \mathrm{~d}$ from treatment.

Of the chemical treatments, the Carbaryl and the Permethrin treatments produced mortality figures that were not significantly different from the controls;

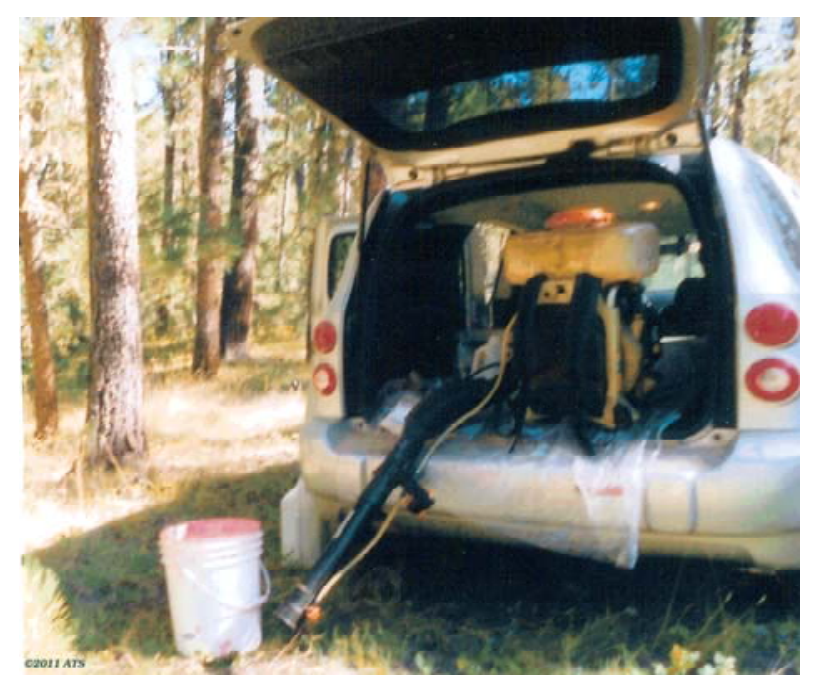

Fig. 4 Rented Chevy HHR cruiser loaded with gear at an unobtrusive location on the Black Hills National Forest. the Lindane and the disodium octaborate treatments did produce significantly higher mortality than the controls; the Lindane treatment produced the best results. In earlier days, the substitution of diesel oil for water would have probably raised the mortality figure further. Though, untested in this study, the author added a $0.3 \%$ organosilicate surfactant to the disodium octaborate treatment, which is left for the folks at Mystery Mountain. As a GS-4 forestry aide on the Umatilla National Forest in Oregon in 1967, I discovered that the addition of a bit of dish soap to a water solution poured on Lodgepole pine log, caused penetration of the water to the cambium and allowed for easy debarking for use as fence rails. The organosilicate acts as a super dish-soap and should move a toxic concentration of borate to the cambium, where the grubs are located.

Of the biological treatments, the $B$. thuringiensis var. San Diego and the Metarhizium produced mortality, which was not significantly different from the controls; but "Our fungus" and the Steinernema worms did produce a significant kill. Cadavers were examined under the microscope. One dead grub from the control group yielded a rod shape Corynebacterium (C. diphtheriae is a human pathogen of the lung). One of the dead grubs from the Metarhizium group produced heavy Cladosporium or Metarhizium from the cuticle.

\subsection{Field Treatments at Mystery Mountain 2009, 2011} and 2013

Treating marked infested trees at Mystery Mountain at odd-years produced results, which could be nuanced and could yield intuitive inferences after close examination.

From Table 2, it can be seen that, while the beetle mortality in the Black Hills was rising dramatically during this period, the number of new hits at Mystery Mountain was actually declining. Death of pine trees is caused by an infection of a Ceratocystis fungus, which is inoculated into the pine tree by the female beetle at 
Table 2 Trees treated and mortality at Mystery Mountain, 2009-2013.

\begin{tabular}{lll}
\hline Date & Green hits sprayed & Died trees \\
2009 & September 3-4, & 53 \\
2011 & September 3 & 42 \\
2013 & December 3 & 13 \\
\hline
\end{tabular}

egg-laying time. Therefore, subsequent death of trees may be irrelevant to the actual suppression of new beetle emergence following treatment. The effectiveness of the spray is best gauged by the decline in new beetle hits, even though a treatment was skipped in years 2010 and 2012. The initial spray treatment at Mystery Mountain was made on September 3-4, 2009, when the high temperature was still hovering around $90{ }^{\circ} \mathrm{F}$. On about July 5, 2010, we made an observation trip (no treatments) to Mystery Mountain and the Black Hills. By that time, just two of the treated trees had died and two new hits were recorded. These would have undoubtedly been two of the 12 dead trees recorded in 2011. One of the trees from the 2009 treatment was a complete failure-boiling with beetle grubs, and had to be felled, with the trunk sprayed with Tim-bor to prevent further infestation. This failure might be explained by the high ambient temperatures at the time of the spray.

The second treatment trip to Mystery Mountain occurred on August 31, 2011, towards the end of the beetle flight period. Forty-two new beetle hits were found; some were hit a few times and may have been "pitched out" by the trees, but some were loaded with beetle hits, requiring careful spray and monitoring in 2012. Some (about 10) trees were hit late in 2010 after our examination of July 5 . These trees were already dead and had spread infestation to the surrounding stand. The "Pork'n'beans" spray treatment was made over a $3 \mathrm{~d}$ period with the high temperature running to $95^{\circ} \mathrm{F}$ - not ideal for these biologicals. Chokecherry (Prunus sp.) trees growing in the understory that were grossly infested with occluded scale, were also sprayed with "Pork'n'beans". The rationale was that these insects, with known susceptibility to "Our fungus", would build a reservoir of inoculum on the property and help keep the beetle hits down.

The illness and death of Art Janklow II during 2012 to the middle of 2013, prevented any follow-up on the Mystery Mountain property until our 3rd trip there on October 28-November 4, 2013. Not only had the weather cooled, but a historic snowstorm had occurred on October 4, which broke up 208 pine trees on the property - far greater damage than the beetles done to date. A second snow storm bottled us up on the property for the first two days. Only 12 of the 42 active "hits" of 2011 were dead, and the rest were green and healthy. By this time, the pitch tubes from the survivors of the 2009 treatment had mostly rubbed off. Only two trees were hit and died during all of 2012 on the entire more than 40 acre property. One of the authors recommended to use the Anderson method for beetle control for 2014: make log piles of six trap log each scattered around the property. After the beetle flight of 2014 is over, either debark the logs or spray them with Tim-bor. The authors sprayed only 13 new hits this time. Wetter weather and more inoculum on the site probably contributed to better spread of "Our fungus" and poorer survival of bark beetles.

\subsection{Black Hills National Forest Treatment Plots, 2009, 2011 and 2013}

Two plots of about 20 acres each were maintained on the Black Hills National Forest for this entire period. Due to bad relations with the United States Forest Service (USFS) and South Dakota (SD) forestry, these plots are demanded to be kept unobtrusively. Both were located in the middle of large and very active beetle-kill zones. These were probably a worst-case scenario with the death of trees and the spread of beetles absolutely certain. One was located above the Deerfield Junction above Hill City, $\mathrm{SD}$, and the other was located near Rocheport, SD. Both of these plots are connected by a massive beetle kill that runs to Mount Rushmore and towards Custer, SD, including all of Harney Peak. Results of the period are summarized in Table 3. 


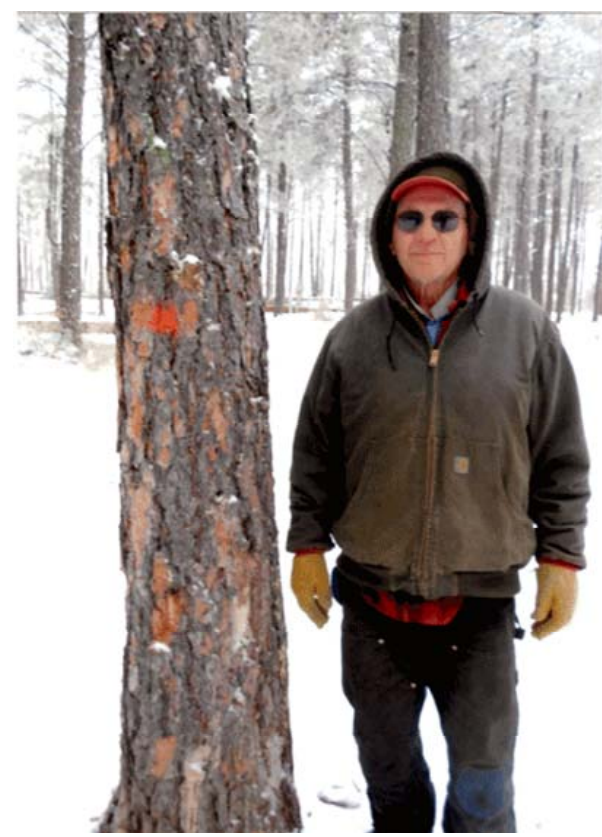

Fig. 5 Darrell Magnus with a survivor pine tree at Mystery Mountain, October 29, 2013.

Table 3 Summary of two plots on Black Hills National Forest property.

\begin{tabular}{llll}
\hline Year & Treated & Died & Still alive \\
\hline 2009 & 95 & - & - \\
2010 & 0 & 85 & 10 \\
2011 & 330 & 85 & 10 \\
2013 & 0 & 320 & 10 \\
\hline
\end{tabular}

-: Means no figure because this was the first year and a figure here is moot.

Ninety-five trees were sprayed at these two locations initially about September 5, 2009. Some of the hits ran fully up to 30 feet up of the trunk and required the full capacity of the mistblower. We averaged 20 trees/16 L tank mix of "Pork'n'beans". Green hits were marked with an " $A$ ", and dead trees, not sprayed in the stand were marked with a cross. Many hits on the edges of these areas remained untreated, due to insufficient time and materials. Only 10 trees survived to 2010 and remained to 2011. These were found trees marked with green crowns and pristine cambium (no beetle galleries seen under sample cut-outs). But, there were very few new hits observed in the margins of these two areas. By 2011, the beetles were rolling again and 330 new trees were sprayed and painted. It took seven tanks of spray to cover 330 trees this time. This is a massive area of beetle kill, with hit trees moving uphill, but a few trees from the class of 2009 still alive, including a $30^{\prime \prime}$ pine down slope.

We didn't spray any trees on Black Hills National Forest (BHNF) property in October 2013, but reviewed the two plots. This time, almost all of the 330 trees sprayed in 2011 were dead. There were only 10 trees left alive. In the four years since the first treatments of 2009, extensive root rot, conks of Fomes applanatus and windthrow were evident. But, unlike in 2011, there were no new beetle hits seen on the green trees at the lower end of the kill area. It was unsafe to walk through and check the upper side. Nearby pine thinnings also had a high percentage of blowdown. This may be due to Annosus root rot. Treatment for this condition included cut stumps spray at the time of thinning with borates or urea. This procedure is also unknown in the Black Hills. Perhaps, we had twice tapped the brakes on the rolling beetle front and stopped them here.

\subsection{Results of Tree Treatments in Billings and Laurel,} Montana, 2009

Four treatment areas were set up in the Laurel-Billings area in 2009. Two hundred "green hit" pine trees were sprayed in Billings city park in October 2009. Though still green in the following spring, all trees were removed by the city.

Twelve trees were treated at 1331 ridge road in Laurel, Montana on September 8, 2009. Of these, nine were still alive on July 12, 2010. There were 154 trees surrounding the Caterpillar Tractor franchise on the south service Rd. @200 blvd. exit I-90. They were mostly Ponderosa pines mixed with some Scots pine. This study was complicated with random application of Verbenone patches and poisoning of some trees with Pichloram herbicide. In 2010, we tallied 24 treated trees, and eight were dead for a mortality rate of $33 \%$. 


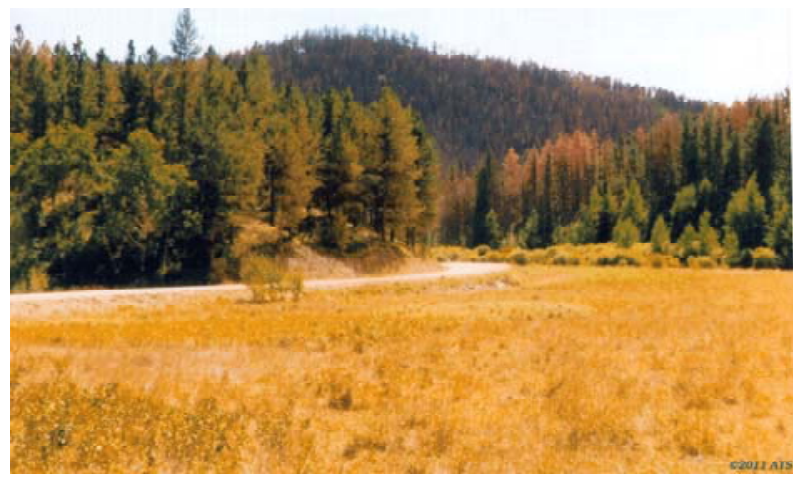

Fig. 6 BHNF beetle kill area near Rocheport, SD.

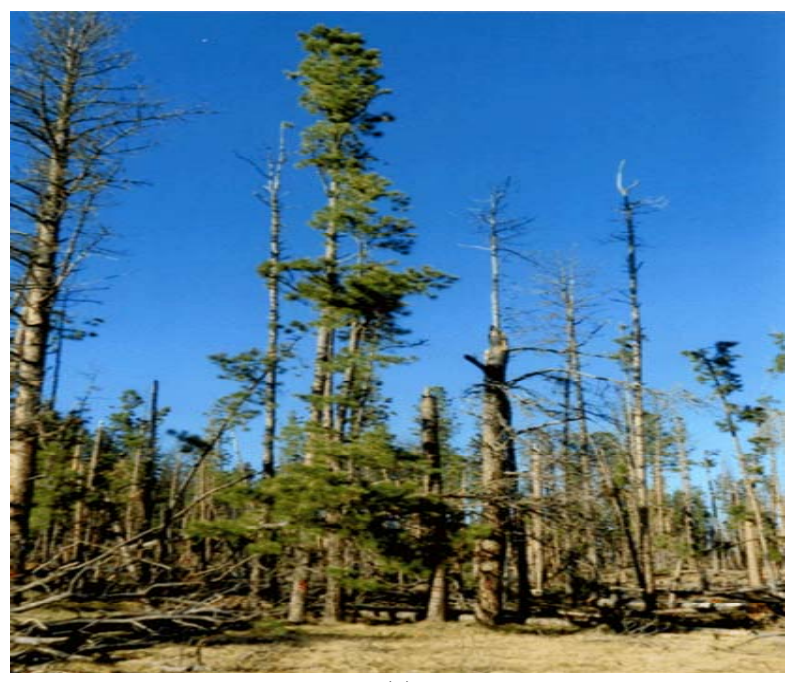

(a)

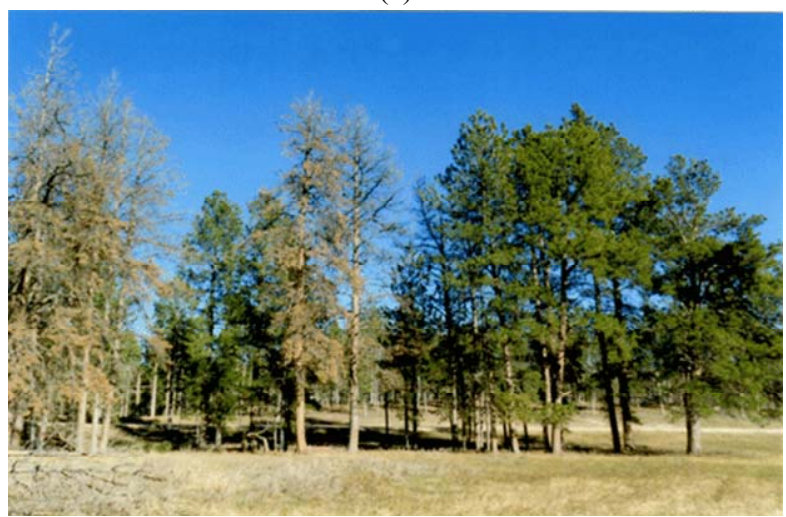

(b)

Fig. 7 a \& b BHNF plots, October 2013, few survivor trees and green trees at edge have no hits on trunks.

The grounds of a private home located on the rimrock below the Billings Airport, had 30 pine trees hit, which then were sprayed with "Pork'n'beans" in October 2009 . There was $100 \%$ survival noted on July 10, 2010. As of November 2013, $100 \%$ of these trees are still alive.

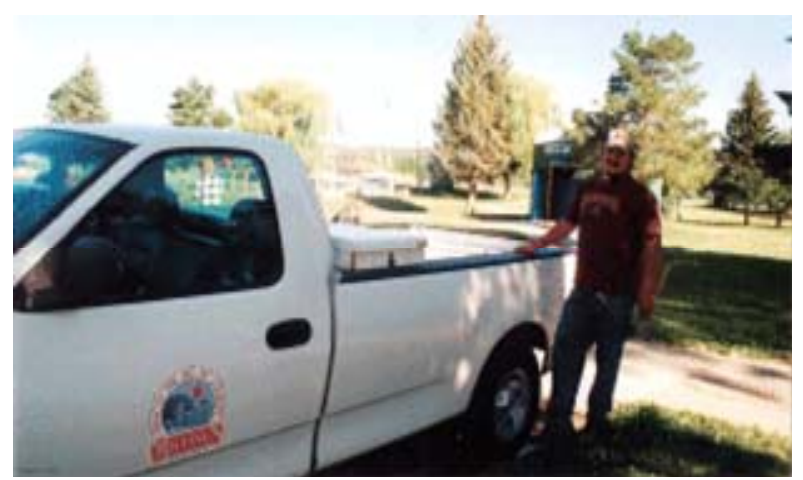

Fig. 8 City forestry bureaucrat explaining that all treated trees had been removed anyway, despite the fact that they were still alive.

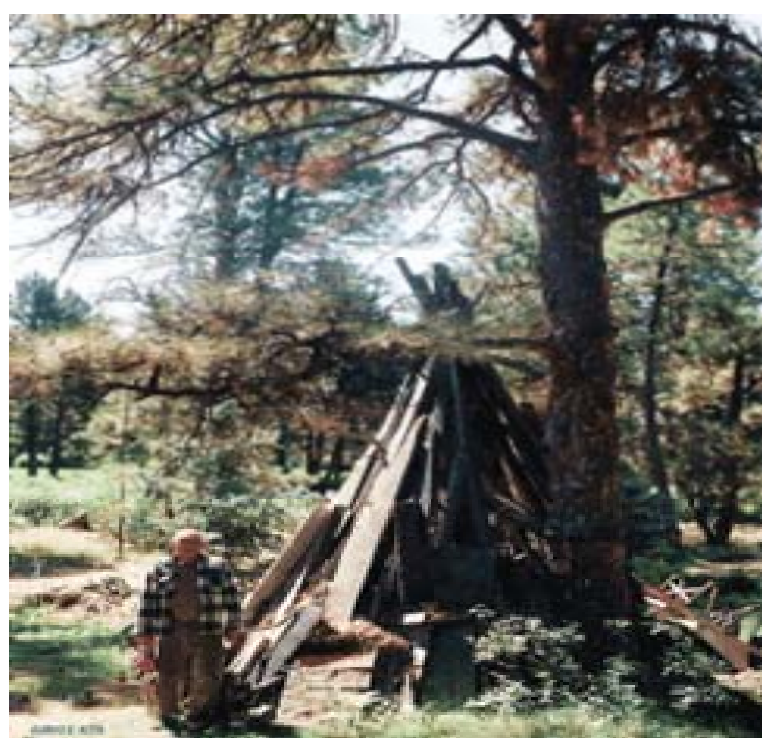

Fig. 9 Surviving pine tree on a private estate in Billings, Montana, note beetle hits from previous year on trunk.

Two hundred and fifty Ponderosa pine "green hits" were sprayed with "Pork'n'beans" on a 160 acre ranch off Highway 287 North of Fort Collins, Colorado, on September 10, 2009. By this early date, upon examining the cambium around a nuptial chamber, it was noted that the eggs had already hatched and each young grub had already tunneled an inch from the nuptial chamber. These trees were cut down and removed within a year of treatment, but were still alive and green at the time.

\section{Discussion}

Landowners are seeking to disinfest the bark beetle-ridden pine trees on their property, but have 
few options available to them. They can fell the infested trees and either debark them or remove them to a location at least 2 miles away. They can bag every $\log$ in plastic and attempt to kill the larvae by solarization [8] (very impractical). They can use large quantities of poor insecticides on their entire stands, or Verbenone patches in an attempt to repel beetles. Repellency is also a poor option, because it simply shifts the mass flights of beetles and tree damage somewhere else. Bark beetles have a flight range of over a mile. The total damage potential to the forest remains the same.

The authors are puzzled and have debated the reasons for the bad behavior, which they have experienced from government forestry over the years. They have tried to come to grips with the underlying rationale behind the efforts to quash (perhaps naive) and control a pest, which is causing the death of millions of acres of trees. Why would people behave this way?

The value of all of corporate America is continuously and instantaneously set by securities trading - a small percentage of the total number of outstanding shares on the floor of the New York Stock Exchange (NYSE) and other exchanges. The owner of a herd of cattle on a ranch can value the entire herd on the basis of the prices for a few animals sold to an abattoir. In the case of the 190 million or so acres of public forest managed by the United States Forest Service, the sales and harvest of timber on public lands have been almost eliminated by misguided environmentalism and bureaucratic inertia. In addition, the lack of a single-payer national health plan places American loggers at a disadvantage against other nations in this low-paying and dangerous occupation. Our workmen's compensation rates run 10 times higher than those in Canada. It is cheaper to cut a tree, mill the lumber and ship it to the United States from Canada and even Siberia than to produce it at home. Therefore, the market value of all the green timber on Federal lands is zero. But, dead timber produces better forest fires and paychecks for fire fighters and the aircraft industry. Instead of cutting a million acres of allowable cut of usable wood into perpetuity (this is called "Forest Management"), people are now burning 5 million acres of trees every year. Don't expect any progress with bark beetle control from federally-employed scientists any time soon!

State government also has a conflict of interest as well. In order for a pesticide to be legally labeled for use in the United States, it must pass muster with the EPA. The test for efficacy and safety costs millions of dollars. Then, the candidate pesticide must pass muster with each state, where sales would be expected. In a state like South Dakota, payments for a shoddy test program with only a few potential clients, might look like a bribe in the minds of chemical company executives. They might not want to bet the up-front costs against potential profits. The Federal Insecticide, Fungicide and Rodenticide Act (FIFRA) allows for unregistered use of bio-pesticide as long as they are of domestic origin. We believe that the agriculture enforcement arm of the states of South Dakota and Montana had overstepped their authority, when they threatened us. This policy seems to be more self-serving than beneficial to the public. Also, additives, adjuvants, stickers and anti-desiccants are not regulated by pesticide laws in the various states. It is not illegal to spray molasses on plants on your property.

Disodium octaborate and associated chemicals are very safe. They are active ingredients in safer insecticide products. Boric acid is used as an eye wash. Borates have been added to water used in air drops on large forest fires and have been as a stump treatment for conifer thinnings to keep Annosus root rot out of the stand. The product is labeled for bark beetles; but since the product is cheap and probably lost its patent protection, there is little incentive for a manufacturer to market it in a low-population Northern state.

It is easy to visualize that thousands of microscopic nematodes crawl around on pine bark and find the 
oviposition holes so that the beetle grubs increase and pine bark was devoured. It is harder to visualize that a fungus with only a rudimentary mycelium finds its way through 2 inches of pine bark to its quarry. The known method of spore dispersal makes "Our fungus" a very good candidate for dis-infested large areas of forest. The work at Mystery Mountain suggests that it can move from a treated tree to an untreated tree nearby and kill those beetle grubs as well. By creating a reservoir of infection using other insects (particularly orders Homoptera and Hemiptera), we can create a multi-year dome of protection for forest property. It would be logical to plan a scouting operation of the Black Hills in August, and begin to spray trees in mid-September, continuing until snow and bad weather shut the operation down. Further scouting could continue during mild periods all winter with spraying resuming in the spring. The observation that "Our fungus" can move to untreated trees on Mystery Mountain, where leaves the door open to the use of helicopters in a general area-wide spray program of inaccessible areas.

Berryman [9] plotted population curves for pine bark beetles, showing a rise from low endemic levels to high epidemic levels and back down again. The falling curve may be due to a lack of food, when the supply of live pine trees runs out. It can also be caused by a rise in the numbers of parasites and predators. Entomophthoralean fungi are ideal parasites; they are able to muster an explosive growth and reproductive rate, kill bark beetles in the egg and in the larval stages and then disappear from the environment like smoke, completely undetectable by scientists.

\section{Conclusions}

The data recorded here shows that controlling the Mountain pine beetle infested forests with the use of Entomophthoralean fungi in a tank mixed with the nematode pathogen Steinernema carpocapsase is not only possible, but economical. Considering the biology of both the bark beetles and these pathogens, the affected forest would be recommended towards the end of the mating flight season. For the Black Hills, this would be during the months of September to October. Infested areas could be scouted from aerial photos or a windshiled survery of the forest from logging roads. Trunks of individual "green hit" trees need to be marked with log marking paint in the direction of the road. The numbers of trees should be tallied and the exact location of the infested area must be located by GPS or by map coordinates. Spraying the trunks with the "Pork'n'beans" mixture should be delayed until ambient temperatures occur within 5-35 ${ }^{\circ} \mathrm{C}$ to correspond to the most active range for both the fungus and the nematode. Spraying should be halted once freezing weather occurs and snow falls. Tree marking and locating can continue throughout favorable periods in the winter. Spraying can resume in the spring with an expectation of higher tree mortalities, but suppression of new beetle emergence (The original 2002 study was done in the spring). The fact that infestation was suppressed at Mystery Mountain in off-years may indicate the possibility of using an indirect spray from helicopters in remote and rugged areas. Considering the amount of catastrophic damage done to timber on the forests of the Western United States every year, this method should not be ignored by forest managers, let alone be suppressed.

\section{References}

[1] Anderson, R. F. 1966. Forest and Shade Tree Entomology. NY: John Wiley \& Sons Inc., 428.

[2] Hain, F. 1970. "Scouting and Treatment." M.Sc. thesis, School of Forestry, Duke University, Durham, NC.

[3] Spears, A. T. 1921. "Massospora cicadina Peck: A Fungous Parasite of the Periodical Cicada." Mycologia 13 (2): 78-82.

[4] Vincent, C., Goettel, M. S., and Lazorovits, G., ed. 2007. Biological Control: A Global Persepctive. Wallingford, UK: CABI.

[5] Scheenberger, N. F. 1996. "Gypsy Moth Populations Plummet in 1996 while 'the Fungus' Skyrockets." Gypsy Moth News 42: 1-2.

[6] Steinkraus, D. C. 2005. "Mass Harvesting of the 
Entomopathogenic Fungus Neozygites fresenii from Natural Field Epizootics in the Cotton Aphid Aphis gossypii." J. Invert. Path. 88 (3): 212-7.

[7] Fuxa, J. R., Ayyappath, R., and Goyer, R. A. 1998. Pathogens and Microbial Control of North American Forest Insect Pests. USA: USDA Forest Service, 4-8.

[8] Negrón, J. F., Shepperd, W. D., Mata, S. A., Popp, J. B., Asherin, L. A., Schoettle, A. W., Schmid, J. M., and Leatherman, D. A. 2001. "Solar Treatments for Reducing Survival of Mountain Pine Beetle Infested Ponderosa Pine Logs." Research Paper RMRS-RP-30, USFS. Accessed April 20, 2015. http://www.fs.fed.us/rm/pubs/rmrs_rp030.pdf.

[9] Berryman, A. A. 1990. Forest Insects: Principles and Practice of Population Management. London: Plenum Press, 287. (in Russian)

[10] Juttner, A. S. 2000. "Of Terrible Tree Pruning and Formosan Termite Mega-Colonies.” Tree Care Industry, October.

[11] Juttner, A. S., and Checkman, D. P. 2002. "New-Age Remedies for Mountain Pine Beetle in the Black Hills." S.D. Div. of Res. Consv. \& Forestry.

[12] Juttner, A. S. 2006. "Therapy for Trees Can Mean Profits for You." Tree Care Industry, November.

[13] Juttner, A. S. 2011. "The South Dakota Bark Beetle Caper." Presented at Entomological Society of America Convention, Reno, Nevada.

[14] Khetan, S. K. 2001. Microbial Pest Control. New York and Basel: Marcel Dekker, 300.

[15] Rottke, L. 1997. "Wanderlust Strikes Again.” Arbor Age, August.

[16] Smith, R. H., Trostle, G. C., and McCambridge, W. F. 1977. "Protective Sprays Tests on Three Species of Bark Beetles in the Western United States." Journal of Economic Entomology 70: 119-25.

[17] Steinkraus, D. C., and Humber, R. A. 1998. "Entomopathogenic Fungus Workshop." Presented at Entomological Society of America Convention, UNLV, Las Vegas, NV.

[18] Thomas, G. 2002. "Off the Menu: Termites Unable to Stomach Wood Treated with New Borate Process." New Orleans Times-Picayune, June 2002.

[19] Humber, R. A. 1998. Entomopathogenic Fungus Identification. Ithaca, N.Y.: ARS, USDA, 26.

[20] Alexopoulos, C. J. 1962. Introductory Mycology. N.Y.: John Wiley \& Sons, 613. 